\title{
Enhancement of domestic wastewater treatment under long sewer line condition in a laboratory set-up by Aspergillus niger bioaugmentation
}

\author{
Lacina Coulibaly $^{1 *}$, Spiros N. Agathos ${ }^{2}$, Germain Gourène $^{1 * *}$ \\ ${ }^{1}$ Laboratoire d'Environnement et de Biologie Aquatique (LEBA), UFR- Sciences \\ et Gestion de 1'Environnement, Université d'Abobo-Adjamé, 02 BP 801 Abidjan \\ 02, Côte d'Ivoire. (E-mail:* coulacina2003@yahoo.fr,**gourene@uabobo.ci) \\ ${ }^{2}$ Unit of Bioengineering, Catholic University of Louvain, Place Croix du Sud 2 \\ Bte 19, 1348 Louvain-la-Neuve, Belgium. (E-mail: spiros.agathos@uclouvain.be)
}

\begin{abstract}
The effect of Aspergillus niger bioaugmentation on COD and protein removal in domestic wastewater under sewage conditions was assessed. The sewer simulating bioreactor was running at a hydraulic retention time of $17 \mathrm{~h}, 20^{\circ} \mathrm{C}$ and $\mathrm{pH} 7.8$ under aerobic condition. When A. niger was bioaugmented, $45 \%$ to $72 \%$ of COD was removed compared to $28 \%$ to $48 \%$ removal of COD in the control at the same period. An overall protein removal of $66 \%$ resulted when A. niger was bioaugmented compared to $29.7 \%$ in the control. Regarding enzymatic activities, we observed that as long as the bioaugmented system biomass concentration was higher than the control, the enzymatic activities were also higher. This research is an initial investigation on wastewater transformation under transitory conditions by $A$. niger and demonstrated the capacity of $A$. niger to remove both COD and protein under actual conditions. A. niger bioaugmentation under sewer conditions could be an alternative for wastewater treatment with a valorisation of fungal waste biomass.
\end{abstract}

Key words-Aspergillus niger, sewer, wastewater, enzyme, API ZYM.

\section{Nomenclature}

COD: Chemical oxygen demand

SEWAP: Sewer wastewater pre-treatment system

LLD: Laser level detector

HRT: Hydraulic Retention Time 


\section{INTRODUCTION}

Nowadays, wastewater treatment acquires substantial funds of countries and this is viewed to heighten in the future. In developing countries, water resource pollution will reach the critical level if alternative processes are not developed and adapted to actual scenario in treating wastewater. Wastewater treatment in sewer line by bioaugmention with well-selected microorganisms or development of sewer biofilm could be alternative technologies to prevent this problem (Koch and Zandi, 1973; Green et al., 1985; Hvitved-Jacobsen et al., 1998; Warith et al., 1998; Coulibaly et al., 2002; Coulibaly and Agathos, 2003). Green et al. (1985) have already proposed bioaugmentation of indigenous bacteria; but it has not been performed and developed. One of the explanations for this lack of interest could be the high concentration of required mixed liquor. Aspergillus and Trichoderma are widely used in industries to produce enzymes. The residual biomasses of these fermentations are often stocked in landfill. Otherwise, as it is well known, active fungal biomass of Aspergillus has relevant potential in pollutant degradation (Coulibaly et al., 2003). We have used $A$. niger under transitory condition to degrade starch as a model polysaccharide substrate and a mixture of this substrate and bovine serum albumin (Coulibaly et al., 2002; Coulibaly and Agathos, 2003). The fungus was capable of transforming biopolymers to easily degradable substrates with simultaneous secretion of enzymes in its growth medium.

The aims of this research were (i) to assess the ability of A. niger in removing chemical oxygen demand (COD) and proteins in raw wastewater under long sewer line condition at hydraulic retention time (HRT) of $17 \mathrm{~h}$ (Ozer and Kasirga, 1995), (ii) to investigate the valorisation in wastewater treatment field of waste biomass of $A$. niger and (iii) to verify the secretion of extracellular enzymes. The strain $A$. niger was chosen after screening of several strains of Trichoderma and Aspergillus for their capacity to excrete hydrolases while growing in domestic wastewater. The fungal biomass was simply produced in the laboratory and a sewer simulating bioreactor was designed to perform the biodegradation test.

\section{METHODS}

\section{Microorganisms and culture conditions}

Aspergillus niger. MUCL 28817 was obtained from the fungal collection of the Catholic University of Louvain (MUCL). The fungus was cultivated on tryptic soy agar (TSA) from Difco laboratories (Detroit, Mich., USA) in $260 \mathrm{ml}$ flat bottle (Nunc, Roskilde, Denmark) containing $40 \mathrm{ml}$ of TSA at $28^{\circ} \mathrm{C}$ for 7 days prior to usage in the reactor system. A. niger was precultured in the medium described by Garcia et al. (1997) containing $40 \mathrm{~g} \mathrm{l}^{-1}$ glucose, $5 \mathrm{~g} \mathrm{l}^{-1}$ meal peptone and $5 \mathrm{~g} \mathrm{l}^{-1}$ casein peptone. Two millilitres of fungal spores collected from 2 bottles of TSA with $20 \mathrm{ml}$ of preculture medium containing $0.1 \%$ Tween 80 were inoculated in a $250 \mathrm{ml}$ baffled flask containing $100 \mathrm{ml}$ of preculture medium. The fungus was grown for 3 days at $20^{\circ} \mathrm{C}$ on a rotary shaker at $150 \mathrm{rpm}$. After 3 days, the biomass was recovered by vacuum filtration under sterile conditions on a Whatman $\mathrm{N}^{\circ} 4$ filter paper. The biomass was suspended and washed in sterile water. The filtration and washing steps were repeated three times. After the third filtration, the recovered fungal biomass was suspended in a $250 \mathrm{ml}$ flask containing $100 \mathrm{ml}$ of sterile water. The biomass was homogenised for 5 min with a tissue homogeniser (Ultra-Turrax, Stanfen, Germany). An aliquot of $50 \mathrm{ml}$ was washed and recovered as above and the biomass was used to inoculate the reactor. 
Reactor system. The sewer simulating system used in this research had been previously described in Coulibaly et al. (2002). It was composed of five stirred tanks in series. The system included one membrane pump (Prominent, CfG, Heidelberg, Germany), which fed the first reactor, and four peristaltic pumps (Gilson, Manupilus 2, Namur, Belgium) linking each reactor to its neighbouring unit. The reactors and the feeding reservoir were agitated with magnetic stirrers (Ika-Combimag RCO, Namur, Belgium). The reactor system was operated at an overall hydraulic residence time (HRT) of $14 \mathrm{~h}$, which is encountered in long sewer lines (Özer and Kasirga, 1995).

Reactor inoculation and sampling. The reactor system was inoculated and sampled in the same way as described in our previous research (Coulibaly et al., 2002). It was filled with $500 \mathrm{ml}$ of raw wastewater. The first reactor was then inoculated with biomass prepared as indicated. The sampling period determination has been described in previous research (Coulibaly et al., 2002).

Wastewater. Wastewater was taken from a Louvain-la-Neuve collector. The raw wastewater was sifted in situ on a $500 \mu \mathrm{m}$ sieve and taken to feed the SEWAP. Approximately 30 litres were preserved at $4{ }^{\circ} \mathrm{C}$ no more than a week for the control, to avoid variation in wastewater characteristics.

Analyses. Fungal biomass was determined by dry cell weight (oven drying at $105^{\circ} \mathrm{C}$ for $24 \mathrm{~h}$ ) and COD was determined by the dichromate method NBN-T 91-201. Proteins were determined by multiplying the organic nitrogen portion by 6.25 (Sridhar and Pillai, 1973). The organic nitrogen portion was determined by the difference between the total nitrogen (Kjeldahl method, NBN-T 91-255) and ammonium (NBNT-91 255). Enzymatic profiles, on the other hand, were determined with the API ZYM kit from bioMerieux (Marcy-l'Etoile, France) and the manufacturer's instructions were followed throughout. The API ZYM kit is a standardised semi quantitative micro method able to detect 19 different types of enzymes. It has previously been used to screen enzyme profile in environmental research (McKellar, 1986; Boczar et al., 1992; Morgan and Pickup, 1993; Cicek et al., 1998).

\section{RESULTS AND DISCUSSION}

Experiments were performed at a hydraulic retention time (HRT) of 17 hours, $\mathrm{pH} 7.8$ and $20^{\circ} \mathrm{C}$. Figure 1 shows the kinetics of COD removal in the sub-reactors $R_{1}, R_{3}$ and $R_{5}$. The kinetics for sub-reactors $R_{2}$ and $R_{4}$ are not reported because of the similarities between $R_{2}$ and $R_{1}$, and between $R_{4}$ and $R_{5}$. One could observe that COD removal increased from reactor $R_{1}$ to $R_{5}$ (figure 1) in both the bioaugmented system and the control. However, for each of the reactors, COD removal in the bioaugmentation experiment was superior than the control. The increase in COD removal parallel with the reactor order could be explained by the augmentation of the contact time between the pollutants and the biomass. In fact, the HRT in $\mathrm{R}_{1}, \mathrm{R}_{3}$ and $\mathrm{R}_{5}$ were respectively $3.4,10.2$ and 17 h. In $\mathrm{R}_{5}$ (figure 1 . C), $70 \%$ of COD and about $66 \%$ of proteins (table 1) were removed during the bioaugmented process while at the same time and within the same reactor in the control, only $48 \%$ of COD and $30 \%$ of proteins (table 1) were removed. The remaining protein concentrations in the effluents of the bioaugmented reactor and the control were respectively, $22 \mathrm{mg} \mathrm{l}^{-1}$ and $48 \mathrm{mg} \mathrm{l}^{-1}$ (table 1). The equivalent COD of these proteins are $35.2 \mathrm{mg} \mathrm{O}_{2} \mathrm{l}^{-1}$ and $76.8 \mathrm{mg} \mathrm{O}_{2} \mathrm{1}^{-1}$, respectively, in the effluent of the bioaugmented reactor and in the control. 

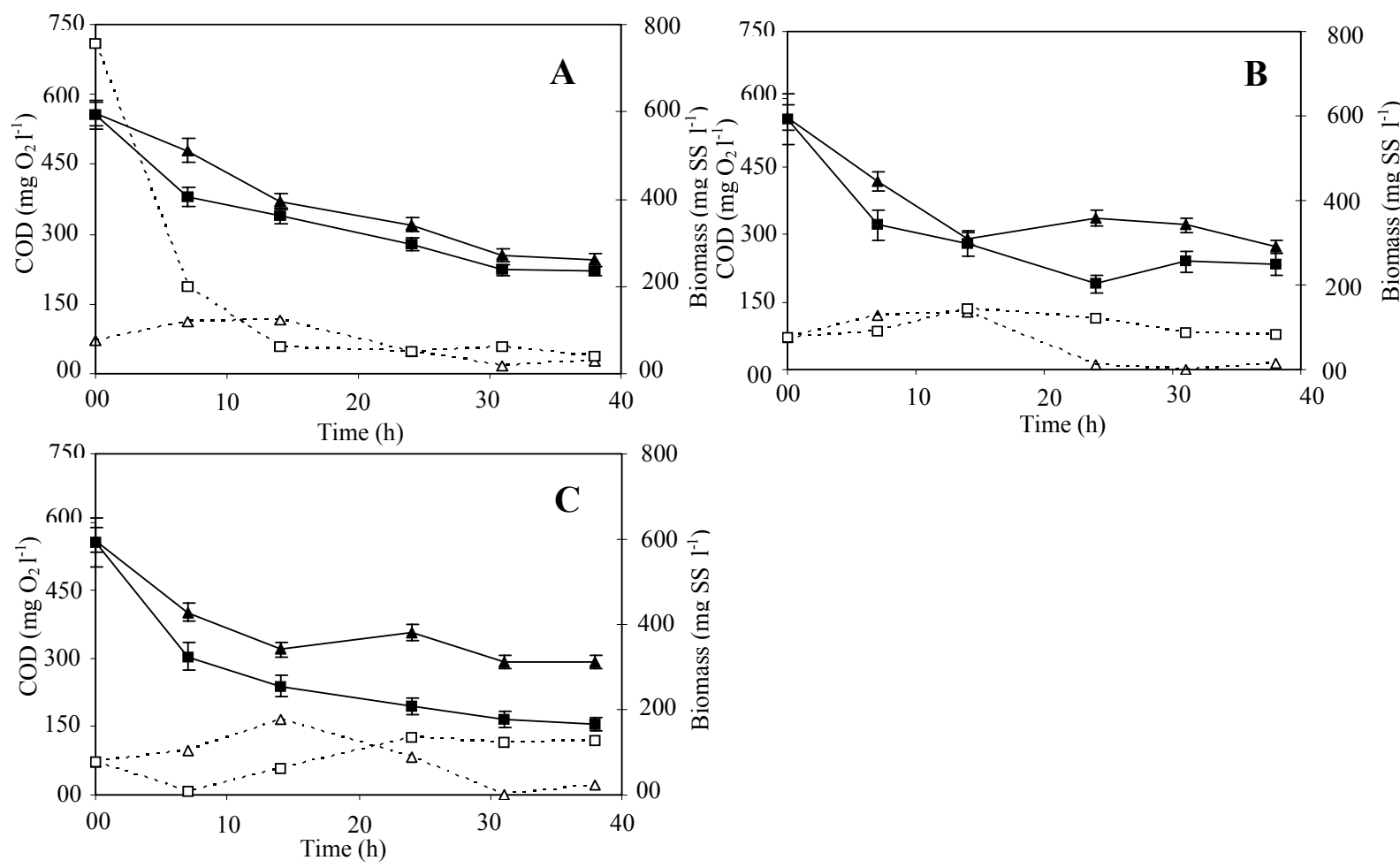

Figure 1. Kinetics of soluble COD removal in domestic wastewater by $A$. niger and the control under transitory conditions. In reactor $\mathrm{R}_{1}(\mathrm{~A}), \mathrm{R}_{3}(\mathrm{~B})$ and $\mathrm{R}_{5}(\mathrm{C})$.

Bioaugmentation with $A$. niger ( - COD,,$\frac{r}{I_{-}-}$Biomass)

Control ( $\triangle-$ COD, $\stackrel{\hat{\Lambda}}{i-1}$ Biomass)

One could observe that proteins constituted the essential of the remaining COD in the effluent of reactor $\mathrm{R}_{5}$. The higher concentration of proteins observed in the effluents of reactors could be explained by their low biodegradability and the decrease in activities of proteases (Lotter and Van der Merwe, 1987; Coulibaly and Agathos, 2003).

The kinetic in terms of COD uptake rate in the sub-system $\left(\mathrm{R}_{1}\right.$ to $\mathrm{R}_{3}$; HRT $\left.=10.2 \mathrm{~h}\right)$ could be compared with the experiment of Green et al. (1985) performed on Tel-Aviv sewerage system $($ HRT $=9.8 \mathrm{~h})$. When $A$. niger was bioaugmented, the initial biomass in the subsystem $\left(\mathrm{R}_{1}\right.$ to $\left.\mathrm{R}_{3}\right)$ was $503 \mathrm{mg} \mathrm{l}^{-1}$. At this biomass concentration, the COD uptake rate was $1.84 \mathrm{~g}^{\mathrm{COD}}(\mathrm{g} \mathrm{SS})^{-1}$ at $31 \mathrm{~h}$ while it was $0.43 \mathrm{~g}$ COD $(\mathrm{g}$ $\mathrm{SS})^{-1}$ when Green et al. (1985) bioaugmented $538 \mathrm{mg} \mathrm{l}^{-1}$ of activated sludge. One could observe that $A$. niger bioaugmentation enhanced the COD uptake rate four times than activated sludge bioaugmentation.

Table 1. Kinetics of protein removal in domestic wastewater by $A$. niger and the control under transient conditions.

\begin{tabular}{|c|c|c|c|c|c|c|}
\hline & \multicolumn{3}{|c|}{ Control Run } & \multicolumn{3}{c|}{ Bioaugmentation Run } \\
\hline Time (h) & $\begin{array}{c}\text { Feed } \\
(\text { Protein, mg 1-1) }\end{array}$ & $\begin{array}{c}\text { Effluent } \\
\left(\text { Protein, } \mathrm{mg} \mathrm{1}^{-1}\right)\end{array}$ & $\begin{array}{c}\text { Removed } \\
(\%)\end{array}$ & $\begin{array}{c}\text { Feed } \\
(\text { Protein, mg 1-1) }\end{array}$ & $\begin{array}{c}\text { Effluent } \\
\left(\text { Protein, } \mathrm{mg} \mathrm{l}^{-1}\right)\end{array}$ & $\begin{array}{c}\text { Removed } \\
(\%)\end{array}$ \\
0 & 67.5 & & 65 & & \\
7 & 67.5 & 57.5 & 14.8 & 75 & 47.5 & 26.9 \\
14 & 67.5 & 37 & 45.2 & 75 & 48.7 & 35.1 \\
24 & 63.7 & 55 & 13.6 & 75 & 52.5 & 30 \\
31 & 63.7 & 39.4 & 38.1 & 75 & 31 & 58.7 \\
38 & 87 & 48 & 44.8 & 75 & 22 & 70.7 \\
\hline
\end{tabular}


Biodegradation mechanism underlying the bioaugmented reactor system was further characterised by analysing enzymatic profiles in the wastewater feed and in $R_{1}, R_{3}$ and $\mathrm{R}_{5}$ effluents using API ZYM kit at $7 \mathrm{~h}, 14 \mathrm{~h}$ and $31 \mathrm{~h}$, respectively (figure 2).

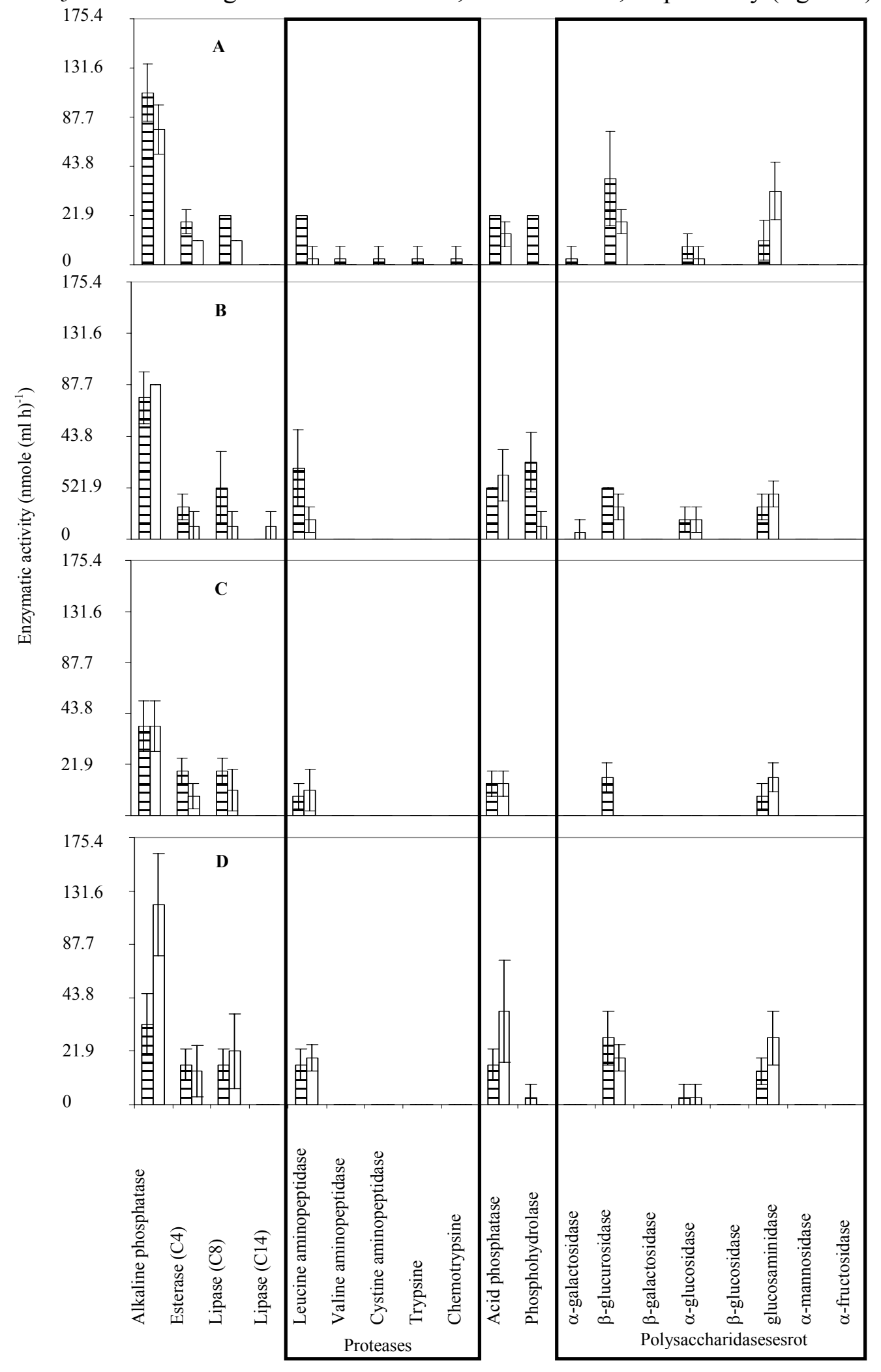

Enzyme

Figure 2. Enzymatic profiles in wastewater under transitory conditions. In feed (A), $\mathrm{R}_{1}(\mathrm{~B}), \mathrm{R}_{3}(\mathrm{C})$ and $\mathrm{R}_{5}(\mathrm{D})$. Bioaugmentation with A. niger ( $\left.\mathrm{O}\right)$, Control ( $\square$ ) 
These periods were selected in order to verify if fungal biomass had an effect on the activities of enzymes in their growth medium. One could observe that at 7, 14 and 31 $\mathrm{h}$, the suspended solid concentration in the bioaugmented reactor was respectively, superior, equal and inferior to the control (figure 1). The conservation of wastewater at $4{ }^{\circ} \mathrm{C}$ influenced the enzymatic profiles (figure $2 \mathrm{~A}$ ). The main enzymes present in the wastewater feed (figure 2 A) were phosphatase (alkaline, acid and phosphohydrolase), cellulase ( $\alpha$-glucosidase, $\beta$-galactosidase, $\alpha$-mannosidase), esterase (C4 and lipase C8) and protease (leucine aminopeptidase). The enzymatic activities of the wastewater conserved at $4{ }^{\circ} \mathrm{C}$ were generally superior to that which was not conserved at this temperature. The enzymes characterized in this research are specific to wastewater (Hankin and Sands, 1974; Verstraete et al., 1976; Lotter and Van der Merwe, 1987; Nybroe et al., 1992; Lemmer et al., 1994) and may not have only bacterial origin, but also human excreta origin (Nybroe et al., 1992). The highest activity of alkaline phosphatase at the beginning of the experiment could have originated from human excreta (Verstraete et al., 1976). They could have some effects of the fungus upon enzyme production in the growth medium (figure $2 \mathrm{BCD}$ ). One could remark that, when the biomass concentrations of the bioaugmented system were superior or equal to the control biomass ( $7 \mathrm{~h}$ in $\mathrm{R}_{1}$ and 14 in $\mathrm{R}_{3}$ ), the enzymatic activities in the former system were essentially superior to the latter. On the other hand, when the biomass concentrations in the bioaugmented system in a sub-reactor were inferior to the control biomass, the enzymatic activities were essentially inversed. The higher phosphatase activity observed at $38 \mathrm{~h}$ for the control in $\mathrm{R}_{5}$ could be the feed activity brought by dilution.

\section{CONCLUSION}

This research demonstrated the possibility to enhance soluble COD and protein removal by augmentation of wastewater with $A$. niger in a sewer simulating system running at a HRT of $17 \mathrm{~h}$. COD and proteins were removed twice higher in the bioaugmentation reactor system than in the control. The findings of this research bring out the $A$. niger applicability in complex media such as sewage. Bioaugmentation of sewage with $A$. niger under transitory condition could be considered for wastewater pretreatment as there is considerably less biomass inoculated. Further investigations are necessary to assess both nutrient removal and bioaugmentation process modelling in order to give an accurate tool for sanitary engineers. This could be more economical for wastewater treatment as well as for the management of $A$. niger waste biomass originating from fermentation industries.

\section{ACKNOWLEDGEMENT}

This research was funded by The Ministry of Higher Education, Scientific Research and Technological Innovation of Côte d'Ivoire. We thank Professor A. M. Corbisier (MUCL) for providing the stock culture of $A$. niger, and special thanks to Dr Pierre Wattiau for suggestions and Hélène-Christine Massart for analytical support.

\section{REFERENCES}

Boczar B. A., Begley W. M. and Larson R. J. (1992) Characterisation of enzyme activity in activated sludge using rapid analyses for specific hydrolases. Wat. Environ. Res. Vol. 64, No. 6, 792-796

Cicek N., Franco J. P., Suidan M. T., Urbain V. and Manem J. (1998) Characterization and comparison of a membrane bioreactor and a conventional activated sludge system in the treatment of wastewater 
containing high molecular weight compounds. Wat. Environ. Res. Vol. 71, No. 1, 64-70

Coulibaly L., Naveau H. and Agathos S. N. (2002) A tanks-in-series bioreactor to simulate macromolecule-laden wastewater pretreatment under sewer conditions by Aspergillus niger. Wat. Res. Vol. 36, No. 16, 3941-3948

Coulibaly L. and Agathos S. N. (2003) Transformation kinetics of mixed polymeric substrates under transitory conditions by Aspergillus niger. African J. Biotechnol. Vol. 2, No.11, 438-443

Coulibaly L., Gourène G. and Agathos N S. (2003) Utilization of fungi for biotreatment of raw wastewaters a Review. African J. Biotechnol. Vol. 2, No. 12, 620-630

Garcia I. G., Bonilla V. J. L., Jiminez P. P. R. and Kirchman L. (1997) Biodegradation of phenol compounds in vinasse using Aspergillus terreus and Geotrichum candidum. Wat. Res. Vol. 31, No. 8, 2005-2011

Green M., Shelef G. and Messing A. (1985) Using the sewerage system main conduits for biological treatment. Greater Tel-Aviv as a conceptual model. Wat. Res. Vol. 19, No. 8, 1023-1028

Hankin L. and Sands D. C. (1974) Bacterial production of enzymes in activated sludge systems. Wat. Pollut. Control Fed. Vol. 46, No. 8, 2015-2025

Hvitved-Jacobsen T., Vollersten J. and Nielsen P. H. (1998) A process and model concept for microbial transformations in gravity sewers. Wat. Sci. Technol. Vol. 37, No. 1, 233-241

Koch C. M. and Zandi I. (1973) Use of pipelines as a aerobic biological reactors. Wat Pollut. Control Fed. Vol. 45, No. 12, 537-548

Lemmer H., Roth D. and Schade M. (1994) Population density and enzyme activities of heterotrophic bacteria in sewer biofilms and activated sludge. Wat. Res. Vol. 28, No. 6, 1341-1346

Levenspiel O., 1972. Chemical reaction engineering. Second edition, John Wiley and Sons, New York, pp. 253-325

Lotter L. H. and Van der Merwe E. H. M. (1987) The activities of some fermentation enzymes in activated sludge and their relationship to enhance phosphorus removal. Wat. Res. Vol. 21, No. 11, 1307-1310

McKellar R. C. (1986) Determination of the extracellular and cell-associated hydrolase profiles of Pseudomonas fluorescens Sp. Using the analytab API ZYM system. J. Dairy Sci. Vol. 69, No. 3, 658-664

Morgan J. A. W. and Pickup R. W. (1993) Activity of microbial peptidases, oxidases and esterases in lake waters of varying trophic status. Can. J. Microbiol. Vol. 39, No. 8, 795-803

Nybroe O., Jorgensen P. E. and Henze M. (1992) Enzyme activities in wastewater and activated sludge. Wat. Res. Vol. 26, No. 5, 579-584

Ozer A. and Kasirga E. Vol. (1995) Substrate removal in longer sewer lines. Wat. Sci. Technol. Vol. 31, No. 7, 213-218

Sridhar M. K. C. and Pillai S. C. (1973) Proteins in wastewater and wastewater sludges. J. Wat. Pollut. Control Fed. Vol. 45, No. 7, 1595-1600

Verstraete W., Voets J. P. and Van Lancker P. (1976) Evaluation of some enzymatic methods to measure the bio-activity of aquatic environments. Hydrobiologia. Vol. 49, No. 3, 257-266

Warith M. A., Kennedy K. and Reitsma R. (1998) Use of sanitary sewers as wastewater pre-treatment systems. Waste Management. Vol. 18, No. 4, 235-247 